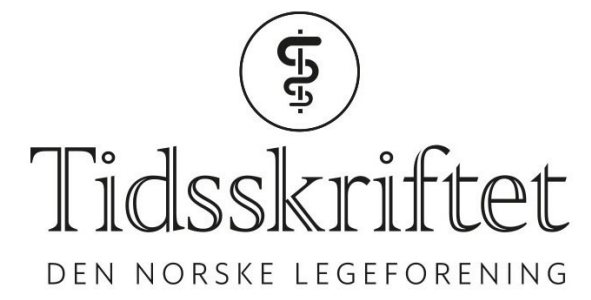

\title{
Kommunikasjon med kirurgisk presisjon
}

PERSONLIGE OPPLEVELSER

EIVIND NORMANN-EIDE

E-post: eivindvilkan@me.com

Eivind Normann-Eide (f. 1973) er psykologspesialist ved Seksjon for personlighetspsykiatri, Oslo universitetssykehus.

Etter flere år med alvorlige og tilbakevendende smerter i magen ble jeg denne høsten lagt inn ved et større norsk sykehus for operasjon.

Norsk offentlig helsevesen høres flott og kompetent ut, noe det også er. Spesialistkompetanse og kirurgisk presisjon er imidlertid ikke mitt poeng. Min personlige opplevelse handler om kommunikasjon, om samtalen mellom lege og pasient og om erkjennelsen av at det også under et somatisk inngrep etableres en relasjon.

Det jeg hadde fått vite forut for innleggelsen, var at de planla å legge meg i narkose og $\mathrm{i}$ første omgang gå inn i navlen, en såkalt kikkhullsoperasjon. Der ville de kunne observere og vurdere tilstanden på innsiden. Om nødvendig ville de åpne opp og utføre en større operasjon. Utfallet var med andre ord langt fra sikkert. For meg som pasient betød det at jeg måtte forberede meg på å sovne inn på operasjonsbordet uten å vite hvilken tilstand jeg ville våkne opp i. Dette gjorde meg skeptisk og redd.

\section{Samtalene}

Samme kveld som jeg sjekket inn på sykehusets pasienthotell, kom kirurgen på besøk. Sammen gikk vi gjennom min sykdomshistorie. Ikke fordi hun ikke hadde lest journalen hun virket godt forberedt - men hun ville kanskje høre den fra meg? Etter samtalen var jeg sikker på at personen som neste morgen skulle skjære i meg, hadde all informasjon jeg var i stand til å gi, at hun hadde forstått det jeg hadde sagt, og at hun fortsatt mente at det var nødvendig med operasjon.

Jeg sov bedre den natten enn fryktet, og jeg følte meg uthvilt morgenen etter, noe jeg i hovedsak tilskrev samtalen kvelden før. På operasjonsstuen kom kirurgen bort, altså samme person jeg hadde snakket med kvelden før. Hun sa hei, informerte meg kort om at de snart var klare, og at jeg nå skulle få snakke med anestesilegen. Det siste hun sa, var at vi ville snakkes på nytt etter operasjonen. Jeg følte meg godt forberedt og sovnet etter kort tid.

Å våkne fra en narkose var som å være et lite barn igjen - sårbar, forsvarsløs og helt avhengig av dem som var rundt. Jeg lå på overvåkningsavdelingen og var våken kun i korte glimt om gangen. Noe av det første jeg husker, er at kirurgen også her kom inn til meg og sa at hun nå ville fortelle meg tre ting: De hadde funnet årsaken til smertene, de hadde ordnet opp i det, 
og det hadde gått bra. Hun sa muligens mer, men det var alt jeg trengte å vite der og da.

Dagen etter hadde jeg den siste samtalen med kirurgen. Jeg var da relativt klar og i stand til å holde en litt lengre samtale. Her fikk jeg en mer grundig gjennomgang av selve operasjonen, hva de hadde funnet, hvordan de hadde gått inn, og hva de hadde gjort. Vi snakket også om årsaken til smertene, hva jeg kunne forvente av bedring, og hva jeg selv burde gjøre for å påskynde rehabiliteringen.

\section{Lytte}

Det er flere forhold i dette som er verdt å understreke. Årsaken til mine problemer var fortsatt uavklart da jeg ankom sykehuset. At det var kirurgen som oppsøkte meg for en grundig gjennomgang i forkant av inngrepet, betydde mye. Hun stilte spørsmål, og hun lyttet. Å lytte handler om nærvær og oppmerksomhet, evne til å ta inn det den andre har sagt, og gi tilbake den informasjonen hun har fått. At det var samme person som tok den forberedende samtalen, gjennomførte inngrepet og informerte, bidro til forutsigbarhet, trygghet og en opplevelse av å ha en viss grad av kontroll.

\section{Relasjonelle råvarer}

De relasjonelle råvarene består her av kontinuitet hva gjelder tid og mennesker, deres evne til å lytte og deres evne til å gi selv helt små doser av informasjon, også til et sinn nedsløvet av smertestillende medikamenter. Dette er råvarer som kan hentes overalt hvor mennesker møtes, og som - jeg vil anta - også spiller en rolle for det somatiske utfallet. Hva dette betyr for legens arbeidstid, vaktordning eller turnus er et annet bord. Men fra et pasientperspektiv vil jeg si tusen takk for at kirurgien var supplert med relasjonskompetanse og kommunikasjon med høy presisjon.

Publisert: 19. mars 2018. Tidsskr Nor Legeforen. DOI: 10.4045/tidsskr.18.0026

(C) Tidsskrift for Den norske legeforening 2020. Lastet ned fra tidsskriftet.no 